\title{
Traditional Criminal Law Existence in the Settlement of Criminal Action in the Environmental Field in Indonesia
}

\author{
Mohamad Syarhan ${ }^{a}$, Nyoman Serikat Putra Jaya ${ }^{\mathrm{b}}$, Bambang Hartono ${ }^{c}$ \\ a Universitas Diponegoro, Faculty of Law, Semarang/Indonesia \\ bUniversitas Diponegoro, Faculty of Law, Semarang/Indonesia \\ 'Universitas Bandar Lampung, Faculty of Law, Bandar Lampung/Indonesia
}

Article History: Received: 10 November 2020; Revised 12 January 2021; Accepted: 27 January 2021; Published online: 5 April 2021

\begin{abstract}
Many cases of environmental pollution and illegal logging have caused alarming damage to the environment. In the Law regarding Environmental Protection and Management, tools to protect the environment have been regulated. One of which is the application of criminal sanctions, but in Indonesia, some laws live in society, one of which is customary criminal law which can also solve criminal acts in the environmental sector. This research aims to analyze the existence of customary criminal law in the settlement of crimes in the environmental sector. This research is legal research with normative juridical research. The results of this study will be presented in descriptive form. The results showed that Hulsman said the criminal justice system had caused suffering because it could not work according to its objectives and did not carry out the principle of accountability. This judicial system had innate defects. In settlement of criminal acts in the environmental sector, examples of customary criminal law are the settlement of fish poisoning cases committed by some Paya Village Village residents. They use fish poison from plants (tuba), Lannet in the form of flour, Bistox in liquid, and Decis, which is liquid.
\end{abstract}

Keywords: Customary Criminal Law, Criminal Act, Environmental Law

\section{Introduction}

The growth and development of environmental law today is increasingly rapid since the introduction of a global environmental policy that originated from human environmental awareness as stipulated in the 1972 Stockholm Declaration. Corporations mostly commit environmental crimes in Indonesia, and usually, damage causes environmental damage and pollution on a large scale (Santosa \& Quina, 2014).

Environmental law has developed rapidly concerning the function of law as protection and certainty for society, but more prominently as a means of development (Siregar \& Zul, 2015). Many factors and problems support the emergence of environmental law, both from environmental problems faced by various countries and cases that arise that threaten and endanger humans. Indonesia is a country where environmental problems are very concerning, and this can be seen both directly and from the mass media (Bodansky et al., 2008).

Many cases of environmental pollution and illegal logging have caused devastating impacts on the environment. Regulation of Environmental Crime in Indonesia Environmental Crime or Environmental Offense is order and prohibition of laws against legal subjects which, if violated, are threatened with the imposition of criminal sanctions, including imprisonment and fines to protect the environment in its entirety and its elements (Kahfi, 2014). Elements in the living environment such as animals, land, air, and water, and humans. Therefore, with this understanding, environmental offenses are not only criminal provisions formulated by Law Number 32 of 2009 concerning Environmental Protection and Management but also criminal provisions formulated into other laws and regulations as long as the provisions are formulated. It is intended to protect the environment as a whole or part of it. 
The provisions of criminal law in Law Number 32 of 2009 concerning Environmental Protection and Management are regulated from Article 97 to Article 120. Law Number 32 of 2009 concerning Environmental Protection and Management explicitly stipulates that environmental crime is a crime (Hendriana et al., 2020).

In modern criminal law principles, including environmental penalties, there are 2 (two) principles widely used today, namely ultimum remedium and primum remedium. Ultimum remedium is an attempt to apply criminal law as a last resort when other legal instruments are ineffective to reduce a crime (Erliyani, 2017). Meanwhile, primum remedium is an effort to apply criminal law as the primary tool to create a deterrent effect both for the perpetrator of a crime and for all people not to commit a criminal act. According to Eddy OS Hiariej, which several experts stated, criminal law must be the last law to be used if other legal instruments cannot be used or function properly. Meanwhile, primum remedium is a modern criminal law theory that states that criminal law is the primary law enforcement tool (Fajrin, 2019).

In social life, especially Indonesian society, cannot be separated from the law. We often hear the adage, namely ubi ius ibi societas (where there is a society where there is the law); therefore, Indonesia becomes a country based on the law (Rechts staat). Indonesian legal system, three legal systems, is inseparable, namely customary law, Islamic law, and western law (Kurniawan, 2016).

Besides that, ethics and norms have long been the standard for social life in a civilized society. Ethics and norms have become the rules that determine whether particular human behavior is appropriate or not. Based on this, people can know what they can expect from others. For a common life, such rules are necessary. Our daily behavior is influenced by many ethics and norms that are not stated in the law, which are sometimes not recognized by national law and are not even disclosed.

The norms that govern human behavior are legal norms. These norms live in association and become rules and laws that bind the community's behaviour and, in many places, are referred to as customary law. In this customary law, there is a law regulating property and kinship matters. There is also law offense customary, which can also be referred to as customary criminal law or customary violation law.

Customary offenses are rules of customary law that regulate events or wrongdoing that disturb the community's balance so that it needs to be resolved so that the community's balance is not disturbed. The Indonesian nation's custom, which is "Bhinneka Tunggal Ika," is not dead but always develops, is always on the move and based on the necessity of always.

Customary Criminal Law is a good thing in legal reform in Indonesia, one of which is renewing the environmental law enforcement system. Customary criminal law regulates actions that violate feelings of justice and propriety that live in the community, thus disrupting the community's peace and balance. The existence of customary criminal law in the community reflects the community's life, and each region has a different customary criminal law according to the customs in that area.

Environmental law development cannot be separated from the world movement to give more to the environment (Ramadhan, 2020). The environment has become a problem that needs to be tackled together to survive in this world. So far, the settlement of criminal acts in the environmental sector committed by individuals or corporations has always been carried out employing formal procedures dominated by the state, which sometimes does not favor the interests of communities local or environmental preservation. Through the formal settlement process through the criminal justice system, sometimes it takes sides with the perpetrators of criminal acts. The excuse commonly used is economic development, whereas, in the current era of Sustainable Development, the role of society is the primary indicator to assess whether the sustainable development policy is successful or not. For sustainable development to be successful, it requires a paradigm shift from the current development model that views indigenous peoples as barriers or risks to be mitigated to develop perceptions that Indigenous Peoples are actors in sustainable development. Based on this understanding, in terms of resolving criminal acts in the environmental sector, it should prioritize local values in society, especially from communities local where the pollution incident occurred, namely settlement through customary criminal law. From the 
problems above, this study aims to analyze customary criminal law's existence in solving criminal cases in the environmental sector.

\section{Materials and Methods}

The research method used is a type of normative juridical research or legal research doctrinal. Normative Legal Research is a legal research conducted by examining library materials or secondary data. Normative legal research is also called doctrinal legal research (Sonata, 2015). According to Peter Mahmud Marzuki, normative legal research is a process to find the rule of law, legal principles, and legal doctrines to address legal issues at hand. In the type of legal research, the law is often conceptualized what is written in the books, or the laws are drafted as rules/norms that are the benchmark of human behavior (Nurhayati et al., 2021).

The data used is secondary data, which is data obtained from literature studies. Secondary data is primary data that has been further processed and presented either by the primary data collector or by other parties. Secondary data is to find initial data or information, get a theoretical basis or legal basis, get limitations, definitions, the meaning of a term. This research is analyzed qualitatively, namely intensive activities that require deep understanding, creativity, and conceptual sensitivity, and the results of the analysis will be presented in a descriptive form. This research method was chosen so that the results of this research can be accounted for academically (Natalis, 2020).

\section{Results and Discussion}

Deforestation, degraded land, depletion of ozone, global warming, oil spills in the sea, dead fish in tributaries due to harmful chemicals, and the extinction of certain species are examples of environmental problems. Live in the moment. Environmental problems literature can be grouped into three forms: environmental pollution, land use, and the depletion or exhaustion of natural resources. However, when viewed from Indonesia's prevailing law, environmental problems are only grouped into two forms, namely environmental pollution and environmental destruction (Subyakto, 2015).

The main difference between environmental pollution and the depletion of natural resources is that pollution can occur due to the entry or birth of a substance, energy, or component into the living environment or certain ecosystem. Thus, substances, energy, or other components are foreign or initially did not exist in a certain area because human activities entered them. Conversely, the depletion of natural resources implies that natural resources that are located or live in their original context are then taken by human activities continuously and uncontrollably in a certain way and a certain amount, causing changes and decreases in the quality of the environment (Ma'ruf, 2019).

The negative impact of decreasing the environment's quality either due to pollution or depletion of natural resources is the emergence of threats or negative impacts on health, decreasing aesthetic value, economic losses, and natural systems disruption (Manisalidis et al., 2020). Environmental law is a field or branch of law that has specific characteristics, namely by Drupsteen. It is referred to as a functional law field because there are administrative law, criminal law, and civil law elements. Therefore, environmental law enforcement can be interpreted as the use or application of instruments and sanctions in administrative law, criminal law, and civil law to force the targeted legal subjects to comply with environmental legislation (Tarlock, 2004).

The use of instruments administrative law and sanctions is carried out by government agencies and citizens or civil legal entities (Rahmad, 2019). A State administration lawsuit is a state administrative tool that can be used by the government that issues state administrative decisions that are formally or materially contrary to the laws and regulations in the environmental sector. Government agencies can only carry out the use of criminal law sanctions. The use of instruments civil law, namely civil suits, can be filed by citizens, civil legal entities, and government agencies.

When environmental problems, especially pollution, have harmed life, many people argue that actions that cause pollution and environmental damage must be viewed as an act against morals and worthy of criminal sanctions for that act can threaten human health and life (Herbig, 2019). These interests fall within the scope of 
criminal law or must be protected by criminal law. Since the Criminal Code as one of the sources of main law criminal does not contain provisions that can be used effectively against perpetrators of environmental pollution or destruction, it is deemed necessary to create or formulate a provision on criminal sanctions outside the Code of Law. This crime or what is more familiar with the specific term law (Hafrida et al., 2021).

Criminal sanctions in environmental law cover two types of activities, namely the acts of polluting and acts of damaging the environment. Actions to damage the environment include, among other things, cutting wood in protected forests, hunting, capturing, and killing protected animals, as well as taking, destroying, and trading protected plant species. In the Indonesian legal system, criminal sanctions that can be imposed on perpetrators of acts of polluting the environment and acts of damaging the environment are contained in several laws and regulations, namely: Law Number 32 of 2009 concerning Protection and Management of the Environment, Law Number 5 of 1984 concerning Industry, Law Number 5 of 1990 concerning Conservation of Living Natural Resources and their Ecosystems, and Law Number 41 of 1999 concerning Forestry.

The formulation of criminal provisions in Law Number 32 of 2009 is a development and revision of the formulation of criminal provisions in the 1997 Environmental Law and the 1982 Environmental Law. Law 32 of 2009 regulates two types of offenses, namely material offenses and formal offenses. Law Number 32 of 2009 formulates material offenses related to environmental pollution no longer using the word and term "pollution environmental" but conceptually does not change the desired meaning and purpose (Widowaty et al., 2021). The formulation of Law Number 32 of 2009 is no longer abstract but more concrete because it uses the term "exceeded ambient or water quality standards." In other words, environmental pollution occurs when ambient air quality standards in terms of air pollution or water quality standards in terms of surface water pollution and seawater standards in terms of marine pollution have been exceeded.

The formulation of this material offense can be found in Article 98 Paragraph (1) and Article 99 Paragraph (1). Article 99 Paragraph (1) that every person who deliberately commits an act that results in exceeding the ambient air quality standard, water quality standard, seawater quality standard, or environmental damage standard criteria will be punished with imprisonment for three years and at the maximum. ten years and a maximum fine of Rp. 3,000,000,000.00 (three billion rupiahs) and a maximum of Rp. 10,000,000,000.00 (ten billion rupiah).

Article 99 paragraph (1) uses a material offense similar to Article 98 paragraph (1). The difference lies in the mental or "mensrea" element of the actor. If the formulation of Article 98 Paragraph (1) is for an act committed intentionally, Article 99 Paragraph (1) the action occurs due to the perpetrator's negligence. Thus, Law 32 of 2009 also

distinguishes material offenses based on wrongdoing (mensrea, schuld) of the perpetrator, namely intentional as formulated in Article 91 Paragraph (1) and negligence formulated in Article 99 Paragraph (1).

Apart from that, Law Number 322009 also recognizes material offenses with two categories of weighting. First, weight gain is related to "causing injury to people or a danger to human health." Weighting in the form of "causing people to be seriously injured and die." Suppose the material offense deliberately committed results in injury or health hazard. In that case, the perpetrator is subject to heavier penalties, namely a minimum of four years imprisonment and a maximum of twelve years, and a fine of at least Rp. 4,000,000,000.00 (four billion rupiahs) and a maximum fine of Rp. 12,000,000,000.00 (twelve billion rupiah). Suppose the material offense deliberately results in serious injury and death. In that case, the penalty of punishment is even greater, namely at least five years in prison and a maximum of fifteen years in prison. Minimum fine of Rp. 5,000,000,000.00 (five billion rupiahs) and a fine maximum of Rp. 15,000,000,000.00 (fifteen billion rupiah).

Suppose the material offense is committed with negligence resulting in injury or health hazards. In that case, the threat of punishment is a minimum of two years in prison and a maximum of six years with a minimum fine of Rp. 2,000,000,000.00 (two billion rupiahs) and a maximum of Rp. 6,000,000,000.00 (six billion rupiah). Suppose the material offense is committed with negligence resulting in the death or serious injury of the person. In that case, the threat of punishment is a minimum of three years in prison and a maximum of nine years or a minimum fine of Rp. 3,000,000,000.00 (three billion rupiahs) and a maximum of Rp. 9,000,000,000.00 (Nine 
million rupiah) (Abdullah et al., 2019). Law Number 32 of 2009 also contains material offenses imposed on the official government who are authorized in the field of environmental supervision. This material offense's imposition is seen as a policy criminal advanced to encourage government officials to implement management environmental seriously.

In addition to offenses material, Law Number 32 of 2009 also contains formal offenses. In this case, there are sixteen offenses formulas formulated in Article 100 to Article 111, then Articles 113 to Article 115. For example, some examples of formal offenses, for example, Article 100, contain Formal offenses concerning violations of wastewater quality standards, emission-quality standards, disturbance quality standards that are punishable by a maximum imprisonment of three years and a maximum fine of Rp. 3,000,000,000.00 (three million rupiah). However, according to Article 100 Paragraph (2), criminal charges based on Article 100 Paragraph (1) can only be carried out if the administrative sanctions imposed are not complied with, or the perpetrator has violated the wastewater quality standard emission-quality standard or disturbance more than once. Criminal charges based on the provisions of Article 100 Paragraph (1) are ultimum remidium which means as a last resort after administrative sanctions are ineffective or not obeyed or the perpetrator of the violation has been more than once. Criminal law is enforced as a last resort because the violation of the wastewater quality standard or the emission-quality standard, or the disturbance standard is a violation of the administrative environment law's provisions.

In the enforcement of criminal law in environmental law, some things escape the state's attention, especially those related to the local wisdom of indigenous peoples. The existence of indigenous peoples in Indonesia is recognized in Article 18 of the 1945 Constitution of the Republic of Indonesia, that division of Indonesian regions into large and small regions with the form of the structure government is determined by law, observing and remembering the basis of deliberation in the system. Government of the state, and rights of origin, especially areas (Priambodo, 2018).

In the explanation of Article 18 of the 1945 Constitution of the Republic of Indonesia, there is approximately two hundred and fifty zelfbesturende landschappen dan in the rule of law theory olksgemeenschappen. Such as villages in Java and Bali, Nagari in Minangkabau, Dusun, and Marga in Palembang. These regions have an original composition, and therefore can be considered special regions. The Indonesian state has the character of respecting the position of particular regions, and all regulations state regarding these regions will remember the rights of the origin of these regions (Ifrani et al., 2019).

Such provision is then reinforced in the Republic of Indonesia Year 1945, resulting in Amendment II. The state recognizes and respects units of indigenous and tribal peoples and their legal rights. Furthermore, recognition of indigenous peoples' existence de jure also recognized and ratified in the 1945 Constitution of the Republic of Indonesia Article 28 I Paragraph (3), which states that traditional communities' cultural identity and rights are respected the times' civilizations. Recognition of indigenous peoples' rights does not stop at the constitution in the environmental sector. Law Number 32 of 2009 regulates local wisdom in six things, namely, first, explaining the meaning of local wisdom (Article 1 paragraph 30, Second, local wisdom is one of the principles of environmental protection and management (Article 2 letter I). Third, the important local element of the ecoregion (Article 7 paragraph 2 letters e and g). Fourth, Local Wisdom becomes an essential element in the Environmental Protection and Management Plan (Article 10 paragraph 2 letter d). Fifth, the government's obligation to regulate the procedures for determining indigenous peoples and their local wisdom (Article 63 paragraph 1 letter $\mathrm{t}$ ), and Sixth, an explanation Article 69, paragraph 1, regarding the exception of the crime of burning forests by indigenous peoples.

The regulation of local wisdom in Law 32 of 2009 contains two fundamental principles: the state must recognize indigenous peoples' existence and their local wisdom in environmental management and protection. Local wisdom becomes the principle and element of environmental management protection. As an implementing regulation for recognition and protection of local wisdom, Minister of Environment and Forestry Regulation Number 34 of 2017 contains five principal regulations, namely; affirming indigenous peoples as agents of local wisdom, regulating the types and criteria of local wisdom, the scope of local wisdom objects to be in customary 
territories, regulating access to local wisdom, and recognition procedures for indigenous peoples and their local wisdom.

The content of local wisdom the regulation in the Minister of Environment and Forestry Number 34 of 2017 points to local wisdom as community intellectual property rights, this can be seen from the legal basis, which also refers to the Nagoya Protocol in Article 2 which explains the purposes and objectives of the Ministerial Regulation for the legal protection of holders and access to local wisdom, and to ensure a balanced benefit-sharing from the use of local wisdom (Humaida et al., 2018).

The framework for regulating local wisdom in this regulation is biased towards the use of local wisdom as "property rights," especially for the benefit of access to local wisdom (individuals, business entities, and others). Consequently, local wisdom as a holistic concept of the relationship between indigenous peoples and nature and local wisdom as practical knowledge in overcoming environmental management problems have not been maximally regulated (Rindarjono et al., 2018).

At least it can be seen from; first, the more detailed and technical criteria for limiting land burning have not been explained based on local wisdom. This Ministerial Regulation does not seem to intend to regulate this matter by not referring to the explanation of Article 69 paragraph (2) of Law Number 32 of 2009, even though the relevant article regulates the same object concerning local wisdom. As a result, the regulation of local wisdom has not fully covered the more technical issues concerning managing land by burning by indigenous peoples.

Second, the recognition of local wisdom has not been placed within the framework of environmental management. Regulation of the Minister of Environment and Forestry Number 34 of 2017 does not explicitly emphasize local wisdom as the basis for environmental management and protection. Both in the preamble and in the trunk, it needs regulation. This Ministerial Regulation only states in its deliberation section that indigenous peoples and local wisdom play an important role in preserving natural resources and the environment. The basis for this consideration implicitly positions local wisdom as a mere supporting element.

In Indonesia's traditional cosmic nature of mind, what is important is prioritizing the creation of a balance between the natural world and the unseen world, between the whole human class and the individual, between the community and the community. Any act that disturbs the balance is a violation of the law, and legal officers are obliged to take necessary actions to restore the legal balance to the reality that customary criminal law is a means of balancing shocks in society due to offense violations, functions to maintain harmony, resolve conflicts, maintain solidarity society, as a reflection of the moral, religious and moral ideals of society and its nature which is not "prae existente". Traditional society believes that humans are part of the macro cosmos (universe), are not separate from God Almighty as His creator, and are united with the natural environment and environment. Their existence is in a position of interrelation and influences each other. In a state of harmony or balance. Therefore violations of this balance must always be returned in a position of balance. According to Ter Haar's view, there is a violation of offense when there is a one-sided disturbance (eenzijdig) of balance and every collision of one aspect of the material life of a person, or of many people who are one unit (group), such actions cause reactions The nature and size of which are determined by customary law customary is reaction (adat reaction) due to which reaction the balance can and must be restored (mostly by payment of violations in the form of goods or money).

So, according to Ter Haar's understanding, to be called an offense must result from shocks in the balance of society. Furthermore, this shock occurs not only when the rules of law in society are violated but also when the norms of morality, decency, and religion in society are violated. For example, what happened in Bali, before 1951, there was a customary offense, "manak salah," that is, when a mother from the Sudra or lower class gave birth to female twins, she must be subject to customary sanctions. After 1951 this provision was deemed inappropriate and therefore abandoned. Customary criminal law has the following characteristics or characteristics: Comprehensive and unifying because it is imbued with cosmic characteristics, which are interrelated with one another. Customary Criminal Law does not differentiate between criminal offenses in nature and offenses that are civil in nature. Open provisions are based on the inability to predict what will happen so that it is not certain so that the provisions are always open to all events or actions that may occur. Differentiating between problems, if a violation occurs, what is seen is not merely the act and its consequences but also the background and who the 
perpetrator is. With this mindset, the search for solutions in an event varies. Judiciary by request, in resolving customary violations based on requests or complaints, demands or lawsuits from parties who are aggrieved or treated unfairly. Actions of reaction or correction, this reaction is not only imposed on the perpetrator but can also be imposed on his relatives or family and can even be imposed on the community concerned to restore the disturbed balance (Marlin et al., 2021).

As described by Van Vollenhoven in "Adat Recht Chapter XI (Adatstrafrecht van Indonesiers) page 745, there are key differences between the criminal law system and the customary criminal law system, namely: A basic subject of the Criminal Code, which can be convicted only a human being (James \& Natasya, 2018). Legal alliances in Indonesia such as villages, relatives, or relatives do not have criminal responsibility for offenses committed by their citizens. In several areas in Indonesia, such as Gayo land, Nias, Minangkabau, South Sumatra, Kalimantan, Gorontalo, Ambon, Bali, Lombok, and Timor often occur, that the village of the criminal or the village where a murder or theft of a foreigner (not a resident of the village) occurred, is obliged to pay a fine or loss to the relative of the person killed or stolen. Criminals, are required to bear the sentence imposed for crimes committed by a person $\mathrm{g}$ its citizens. In short, the Criminal Code adheres to individual responsibility and also recognizes strict and vicarious liability. The second principle from the Criminal Code, is that a person can only be convicted if the act is committed on purpose or because of negligence. In short if he has an error in other terms, the Criminal Code adheres to schuldstrafrecht, that is, besides being proven to have committed the act of being accused, it is also necessary to have an error in the form of deliberation or negligence. Whereas in customary criminal law, this element of guilt is not an absolute requirement, and sometimes there are certain offenses in customary criminal law where there is absolutely no need for evidence of intentional or negligent existence. The Criminal Code system recognizes and distinguishes the problem of helping to commit crimes (medeplichtigheid), cajoling (uitlokking), and participating (mededaderschap) as regulated in Articles 55 and 56. Whereas in customary criminal law, anyone who participates against customary law regulations, are required to participate in fulfilling the business required to restore the legal balance. So all those who participate in committing crimes or fighting offenses must be held accountable.

The expression of Ubi Societas Ibi Ius (where there is a society, there is the law) expressed by Cicero teaches many things about understanding the design of law in society. The law cannot be enforced rigidly, conservatively, and tyrannically. The logic of legal positivism can only be used in a utopia. However, it does not have a practical basis that is effective enough to translate the desires of society. Because people's life is so dynamic and turbulent, full of demands for changes. Law cannot be isolated from the realities that encourage responsiveness, progressive, and egalitarianism in facing social realities. The conception of law in society, it raises a debate between changes about whether society changes the law or laws that change society.

Law is not just for creating order, more than that law must provide a sense of justice for the community. Law does not automatically give birth to justice, but to achieve justice, law must be upheld. The function of law enforcement is to actualize legal rules so that they are in accordance with what the law aspires to be, namely realizing human attitudes or behavior in accordance with the framework established by a statutory regulation or law. A law enforcement system that has good values is about harmonizing values with rules and real human behavior. In essence, the law has an interest to ensure the social life of the community, because the law and society there is an interrelation. The criminal justice system must always promote the interests of law and justice. Whatever theory of justice is used, the definition of justice must include: fairness, impartiality, and appropriate reward and punishment. The issue of justice has become a fairlydiscussion popular when it is related to the process of solving criminal acts.

Settlement of criminal cases is the handling of cases, both cases of general crimes (theft, murder, fraud, etc.) and special crimes or corruption in accordance with statutory procedures. valid invitation with the completion stages. Settlement of criminal cases can be done through 2 (two) processes, namely through litigation and nonlitigation processes.

Hulsman said the criminal justice system has caused suffering, because it is unable to work according to its objectives, does not carry out the principle of accountability and this justice system has innate defects. Thus, it 
appears that what this system aspires to be the opposite. Hulsman has developed a notion of "abolitionism" which disagrees with the existence of punishment which he deems inhuman and irrational. Hulsman concluded that the criminal justice system should be completely abolished because logically it would not be a humane and sensitive means of dealing with crime. In this regard, thesystem justice criminalmust be replaced by anmodel alternative, such as penal mediation. Determining the purpose of punishment is quite a dilemma issue, especially in determining whether punishment is intended to retaliate for the criminal act that occurred, or is a worthy goal of the criminal process, namely the prevention of anti-social behavior. Determining the meeting point of the two views if it is not successful requires a new formulation in the system or purpose of punishment in criminal law. The purpose of imposing a criminal sentence can be seen as follows: retribution views that punishment is retribution for wrongdoing so that it is action-oriented and lies in the occurrence of the crime itself. This theory puts forward that sanctions in criminal law are imposed solely because a person has committed a crime which is an absolute consequence that must exist as a retaliation for the person who committed the crime, so that the sanction aims to satisfy the demands of justice; deterrence, views that punishment is not a retaliation for the perpetrator's wrongdoing, but is a means of achieving a useful goal to protect the community towards the welfare of society. Sanctions are emphasized on their purpose, namely to prevent people from committing crimes, so they are not aimed at absolute satisfaction of justice (Sinambela, 2020).

One of the local wisdom-based dispute resolution is related to the use of customary law. Customary law as a legal system has its own pattern of resolving disputes. Customary law has a distinctive and unique character when compared to other legal systems. Customary law is born and grows from the community, so that its existence cannot be separated from the community. Settlement of criminal cases in customary law communities is based on the living perspective (lebensaacbuung) adhered to by a community. This solution is based on the values, mindsets and norms that have characterized society. In addition, the characteristics of a society that are religious, communal, democratic, emphasize spiritual moral values, and are modest (simple) (Ghebretekle \& Rammala, 2019).

The settlement of criminal cases based on local wisdom, for example, is related to another point of view of seeing the existence of customary courts as a necessity for the formal justice system of power in order to help overcome the overload problem faced by official (state) courts. Many criminal cases will be more efficiently resolved by customary courts, for example minor criminal cases, child crimes or complaint offenses. Settlement of cases through customary courts based on local wisdom and based on deliberation and consensus can further realize restorative justice, so that law enforcement based on local wisdom in their respective regions in Indonesia can be realized.

Local wisdom-based crime resolution can use the Legal Pluralism approach. The Legal Pluralism approach relies on the existence of regulations between the state (positive law), social aspects (socio-legal approach), and natural law (moral / ethic / religion). Legal pluralism is a new approach strategy that law enforcers must master in order to make breakthroughs legalthrough the non-enforcement of law (Tamanaha, 2001). This is because this approach is not imprisoned by the provisions of legal formalism but has jumped towards the consideration of living law and natural law. The method of law in Indonesia is not appropriate if it uses a positivistic approach such as the country of origin of this law, namely Europe without moral/religious or ethic aspects as well as consideration of its socio-legal aspects. The liberal individualistic character of modern law in Indonesia must be dismantled to suit its social basis, namely Indonesian society with its oriental character (local wisdom).

Fish poisoning committed by some residents of Paya Village Gampong using fish poison from plants (tuba), Lannet in the form of flour, Bistox in the form of liquid, and Decis in the form of liquid. This poison is the same as the cyanide poison. In taking fish by poisoning, the poison is often used. so that more fishing is obtained by using this poison. In the case of fish poisoning by some residents of Gampong Kampung Paya it has exceeded the limit, because what is being done does not only affect the fish but also for those who consume the fish obtained from the poisoning (Lahilote, 2020). who consume the catch of poisoned fish will experience effects that cause pain such as stomach pain, vomiting, diarrhea. In this case, it is prohibited for residents not to poison the fish in the river area so that it does not affect the fish and the people who eat them. 
After the stipulation of Paya Gampong Qanun Article 8 Number 10 of 2015 concerning the prohibition of poisoning fish in the village of Paya Village, no one else would commit the act. because they are afraid of the sanctions given to everyone who violates the Qanun. So with the existence of a Qanun, all those who commit criminal acts in Gampong Kampung Paya will be subject to punishment, in enforcing sufficient sanctions regarding penalties for fish poisoning, because with the Qanun, no one will repeat the act anymore. In fish poisoning, there is no socialization from the office to go down to the field to provide a socialization for those who commit fish poisoning in the river. So in the absence of socialization, some residents who poisoned fish were not directed to the better. In the absence of socialization, it does not mean that fish poisoning will continue, but with the existence of an enforced Qanun, this continuation will not be repeated. In the settlement of fish poisoning criminal cases known as customary fines in the form of one goat and enough rice, it is a relief for fish poisoning perpetrators because they do not have to be in detention. The act of poisoning fish by a person in the river Gampong Kampung Paya was resolved according to custom. However, these actions must be punished in accordance with the Qanun that has been stipulated so that the perpetrators of poisoning the fish feel deterred by the actions taken. In this settlement it is carried out by the perpetrators and traditional officials so that the punishment can be resolved fairly (Eka Syafriana, 2018).

In customary law all types of violations have a level of settlement which is always used and obeyed by the community. In customary law, the types of problem solving and sanctions can be done first advising, the next stage is giving a warning, then an apology statement by the guilty perpetrator before the crowd was crowded, usually at the mosque, then he was sentenced to a sentence. This means that the imposition of the punishment is to teach others a lesson so that they do not do the same thing that the perpetrator did. The imposition of sanctions must be considered wisely in accordance with the mistakes committed and taking into account the conditions of the perpetrator or the parties and this is an important thing in order to restore the situation in order to increase public order and harmony. And also the imposition of these sanctions causes disharmony between the perpetrators of customary violations and the community. In terms of settlement as well as the provision of criminal sanctions for customary fines of one goat and sufficient rice by the perpetrator of fish poisoning to the kechik, thesecretary village, the head of tuha peut, and the entire ranks of the gampong apparatus as well as some of the traditional community leaders who participated in the settlement of criminal cases of fish poisoning that were subject to criminal sanctions for one goat and sufficient amount of rice. because they have an important role, namely as mediators/judges in the settlement of criminal acts. In solving the case, it is not justified give toto the family but must be borne by the perpetrator himself. Therefore, the perpetrator is responsible himself for the actions he has committed.

In the customary law of Dayak ngaju, the concept of Belom Bahadat is known. Belom Bahadat as the principle of the customary criminal law of Dayak Ngaju because Belom Bahadat is a good and correct philosophy of life based on the rules and life order of the Dayak Ngaju indigenous people that have been valid and maintained from generation to generation. Belom bahadat has the meaning of three attitude images, namely first the attitude of worshiping God Almighty or peace with God the creator of the universe, secondly respecting fellow humans or peace with fellow humans and the third being polite that is implemented by upholding norms and obeying law for peace and order.

Belom Bahadat as The Living Law of the Dayak Ngaju indigenous people or as the principle of the Dayak Ngaju customary criminal law, so that all acts that are contrary to the principles of Belom Bahadat can be punished. For example, the act of burning forest or land is an act that violates the principles of Belom Bahadat, because burning forests or land results in a haze disaster, damages the environment, and even causes respiratory disease for humans, even though the act of burning forest or land is not regulated in the Tumbang Anoi Agreement or not. is a customary crime, because the Dayak indigenous people have the habit of clearing fields or land by burning. The influence of the times and demands to conserve the environment as the national law prohibits clearing fields or land resulting in shifting, which was not previously prohibited to become prohibited (Penalization), the customary law of Dayak Ngaju should also prohibit through the application of theprinciple Belom Bahadatagainst clearing fields by burning, because National criminal law through environmental laws, forestry laws, plantation laws, and the Criminal Code itself prohibits farming or clearing land by burning. 
Actions that are contrary to the principle of Belom Bahadat will be subject to punishment in the form of Singer and carry out certain traditional rituals to restore the balance that was damaged due to the customary crimes committed, because Belom Bahadat is the rule of life and philosophy of the Dayak Ngaju indigenous people. as in the national criminal law which has acts againstlaw material (material wederrechtelijkheid), which means that even though the act is not regulated in the formulation of written legislation, a person or perpetrator can be criminalized for violating, norms, rules, morals and the values of justice. who live and develop in society (Citranu, 2019).

Customary courts in this natural resource conflict are used by indigenous peoples to protect their living space and humanity, customary law (including customary courts) also applies to parties, whether individuals, communities, or companies, which are deemed to have violated the rights of indigenous peoples over their natural resources. Therefore, the application of customary law and customary courts to companies or outsiders is carried out after efforts by the State law mechanism do not fulfill the sense of justice of the community or are deadlocked. And in facing customary sanctions by companies /outsiders, impose the following sanctions: implement/pay customary sanctions, avoid/refuse customary sanctions; implement/pay some customary sanctions and reject the customary justice system. Although it also requires inresearch -depth, effectiveand company/outside party relations with regard to the enforcement of customary courts, from several cases it depends on the bargaining position of the Indigenous community/community towards outsiders, the higher the bargaining power of the customary community, the higher the possibility. his customary court is effective.

The approach of local wisdom in solving criminal cases is not usually equated from one region to another. However, local wisdom still has the core of a cultural approach that makes use of the local values and culture of the community. This indicates that people who live together in the demands of a value system, will complement their rules with a number of cultured local policies. The goal is of course to anticipate various problems caused by the relationship between individuals and individuals, individuals and communities, and community and community in the relationship between humans as social beings. In addition, local communities also have the ability and sensitivity which is called local wisdom in maintaining the continuity of community dynamics, including anticipating threats and resolving disputes. Empowering local wisdom as an alternative solution in handling disputes, one of which is related to criminal cases with a cultural approach.

\section{Conclusion}

Law 32 of 2009 formulates material offenses related to environmental pollution no longer using the word and term "pollution environmental" but conceptually does not change the intended meaning and purpose. The formulation of Law Number 32 of 2009 is no longer abstract, but more concrete because it uses the term "exceeded ambient or water quality standards". In other words, environmental pollution occurs when ambient air quality standards in terms of air pollution or water quality standards in terms of surface water pollution and sea water standards in terms of marine pollution have been exceeded. Settlement of criminal cases is the handling of cases, both cases of general crimes (theft, murder, fraud, etc.) and special crimes or corruption in accordance with the procedures of the legislation in force with the stages of their settlement. Settlement of criminal cases can be done through 2 (two) processes, namely through litigation and non-litigation processes. Hulsman said the criminal justice system has caused suffering, because it is unable to work according to its objectives, does not carry out the principle of accountability and this justice system has innate defects. Thus, it can be seen that what this system aspires to do is the opposite, therefore in terms of the settlement of crimes in the environmental sector it must be possible to resolve them through other alternatives. What is meant is through customary criminal law. Customary criminal law has the following characteristics: Comprehensive and unifying, because it is imbued with cosmic characteristics, which are interrelated with one another. Customary Criminal Law does not differentiate between offenses that are criminal in nature and offenses that are civil in nature. Open provisions, this is based on the inability to predict what will happen so that it is not certain, so that the provisions are always open to all events or actions that may occur. In the settlement of criminal acts in the environmental sector, examples of the application of customary criminal law are the settlement of cases of fish poisoning committed by some residents of Paya Village Village who use fish poison from plants (tuba), Lannet in the form of flour, Bistox in the form of liquid and Decis. which is liquid. 


\section{Conflict of Interest: No}

Funding Source: Author.

\section{References}

[1]. Abdullah, L. O. D., Dewi, I. K., Gurusi, L., Abdullah, R., Pratiwi, E. T., Mashendra, Ilyas, A., \& Rado, R. H. (2019). The role of buton polres in completing illegal sand criminal actions in kamelanta village. IOP Conference Series: Earth and Environmental Science, 343, 1-11. https://doi.org/10.1088/17551315/343/1/012131

[2]. Bodansky, D., Brunnée, J., \& Hey, E. (2008). International Environmental Law: Mapping the Field. In D. Bodansky, J. Brunnée, \& E. Hey (Eds.), The Oxford Handbook of International Environmental Law (pp. 1-25). Oxford University Press. https://doi.org/10.1093/oxfordhb/9780199552153.013.0001

[3]. Citranu, C. (2019). The Tumbang Anoi 1894 Agreement As A Source Of Adat Criminal Law Of Dayak Ngaju. Tampung Penyang, 17(2), 1-17.

[4]. Eka Syafriana, D. (2018). Sanksi Pidana Adat Bagi Pelaku Pencemaran Lingkungan Di Gampong Kampung Paya Kecamatan Kluet Utara Kabupaten Aceh Selatan (Analisis Pasal 8 Qanun Nomor 10 Tahun 2015). Universitas Islam Negeri Ar-Raniry.

[5]. Erliyani, R. (2017). The Essence Of Primum Remedium Principle In The Enforcement Of Environmental Criminal Law. Journal of Law, Policy and Globalization, 64, 77-84.

[6]. Fajrin, Y. A. (2019). Punishment Asset Forfeiture for Corruptor In Perspective of Indonesian Community Justice. FIAT JUSTISIA, 13(3), 209-230.

[7]. Ghebretekle, T. B., \& Rammala, M. (2019). Traditional African Conflict Resolution: The Case of South Africa and Ethiopia. Mizan Law Review, 12(2), 325-347. https://doi.org/10.4314/mlr.v12i2.4

[8]. Hafrida, H., Helmi, H., \& Permatasari, B. (2021). The Implementation of the Strict-Liability Principle to the Perpetrators of Forest and Land Burning. PADJADJARAN Jurnal Ilmu Hukum (Journal of Law), 07(03), 314-333. https://doi.org/10.22304/pjih.v7n3.a2

[9]. Hendriana, R., Utami, N. A. T., \& Angkasa. (2020). Law Enforcement of Environmental Pollution and Damage. IOP Conference Series: Earth and Environmental Science, 519, 1-5. https://doi.org/10.1088/1755-1315/519/1/012023

[10]. Herbig, F. J. W. (2019). Talking dirty - effluent and sewage irreverence in South Africa: A conservation crime perspective. Cogent Social Sciences, 5(1), 1-18. https://doi.org/10.1080/23311886.2019.1701359

[11]. Humaida, N., Louisa, V. M., \& Lestari, N. C. (2018). Characteristics of The Local Wisdom from South Borneo In Ecological Aspect. ESE INTERNATIONAL JOURNAL(Environmental Science and Engineering), 1(2), 30-34.

[12]. Ifrani, Abby, Barkatullah, Nurhayati, \& Said. (2019). Forest Management Based on Local Culture of Dayak Kotabaru in the Perspective of Customary Law for a Sustainable Future and Prosperity of the Local Community. Resources, 8(2), 1-17. https://doi.org/10.3390/resources8020078

[13]. James, P. M. P., \& Natasya, S. N. (2018). Triangular concept of legal pluralism in the establishment of consumer protection law. E3S Web of Conferences, 52, 1-8.

[14]. Kahfi, A. (2014). Kejahatan Lingkungan Hidup. Al-Daulah, 3(2), 206-216.

[15]. Kurniawan, F. (2016). Hukum Pidana Adat sebagai Sumber Pembaharuan Hukum Pidana Nasional. EDUKA : Jurnal Pendidikan, Hukum, dan Bisnis, 1(2), 13-26.

[16]. Lahilote, H. S. (2020). Legal Transplant in the Substance of the Authority of Religious Courts in Indonesia. Journal of Law, Policy and Globalization, 93, 135-142. https://doi.org/10.7176/JLPG/93-14

[17]. Manisalidis, I., Stavropoulou, E., Stavropoulos, A., \& Bezirtzoglou, E. (2020). Environmental and Health Impacts of Air Pollution: A Review. Frontiers in Public Health, 8, 14. https://doi.org/10.3389/fpubh.2020.00014

[18]. Marlin, M., Patittingi, F., \& Tolo, S. B. (2021). Customary Payment to Achieve A Justice in The Land Disputes. Al-'Adl, 14(1), 57-69. https://doi.org/10.31332/aladl.v14i1.2408 
[19]. Ma'ruf, A. (2019). Aspek Hukum Lingkungan Hidup Dalam Upaya Mencegah Terjadinya Kerusakan Dan Pencemaran Lingkungan Hidup Di Indonesia. Jurnal Wacana Hukum, 24(1), 38-51. https://doi.org/10.33061/1.jwh.2018.24.1.2997

[20]. Natalis, A. (2020). Urgensi Kebijakan Penyelenggaraan Anggaran Pendapatan dan Belanja Daerah dalam Mewujudkan Kesejahteraan Perempuan. Pandecta Research Law Journal, 15(1), 64-73. https://doi.org/10.15294/pandecta.v15i1.23205

[21]. Nurhayati, Y., Ifrani, I., \& Said, M. Y. (2021). Metodologi Normatif dan Empiris dalam Perspektif Ilmu Hukum. Jurnal Penegakan Hukum Indonesia, 2(1), 1-20. https://doi.org/10.51749/jphi.v2i1.14

[22]. Priambodo, B. B. (2018). Positioning Adat Law in the Indonesia's Legal System: Historical Discourse and Current Development on Customary Law. Udayana Journal of Law and Culture, 2(2), 140-165.

[23]. Rahmad, R. A. (2019). The Legal Opinion of Law Enforcement on the Field of Forest and Land Combustion in Riau Polda. International Journal of Innovation, 10(4), 1-10.

[24]. Ramadhan, M. (2020). Juridical Analysis Of The Asean Agreement On Transboundary Haze Pollution And Its Implementation In Indonesia. Lampung Journal of International Law, 1(2), 55-62. https://doi.org/10.25041/lajil.v1i2.2025

[25]. Rindarjono, M. G., Ajar, S. B., \& Purwanto, W. (2018). Local Wisdom in Environmental Conservation. IOP Conference Series: Earth and Environmental Science, 145. https://doi.org/10.1088/1755$1315 / 145 / 1 / 012100$

[26]. Santosa, M. A., \& Quina, M. (2014). Gerakan Pembaharuan Hukum Lingkungan Indonesia dan Perwujudan Tata Kelola Lingkungan yang Baik dalam Negara Demokrasi. Jurnal Hukum Lingkungan Indonesia, 1(1), 23-54. https://doi.org/10.38011/jhli.v1i1.164

[27]. Sinambela, Y. P. (2020). Disparity Of Death Penalthy Decision Against People Criminal Acts Of Dark Circular Narcotics. Asian Social Science and Humanities Research Journal (ASHREJ), 2(1), 9-19. https://doi.org/10.37698/ashrej.v2i1.19

[28]. Siregar, J., \& Zul, M. (2015). Penegakan Hukum dalam Tindak Pidana Lingkungan Hidup di Indonesia. $8(2), 107-131$.

[29]. Sonata, D. L. (2015). Metode Penelitian Hukum Normatif Dan Empiris: Karakteristik Khas Dari Metode Meneliti Hukum. FIAT JUSTISIA:Jurnal Ilmu Hukum, 8(1), 15-35. https://doi.org/10.25041/fiatjustisia.v8no1.283

[30]. Subyakto, K. (2015). Azas Ultimum Remedium Ataukah Azas Primum Remedium Yang Dianut Dalam Penegakan Hukum Pidana Pada Tindak Pidana Lingkungan Hidup Pada Uu Nomor 32 Tahun 2009 Tentang Perlindungan Dan Pengelolaan Lingkungan Hidup. Jurnal Pembaharuan Hukum, 2(2), 201213.

[31]. Tamanaha, B. Z. (2001). Socio-Legal Positivism and a General Jurisprudence. Oxford Journal of Legal Studies, 21(1), 1-32.

[32]. Tarlock, A. D. (2004). Is There: A There There in Environmental Law. Journal of Land Use, 19, 213603.

[33]. Widowaty, Y., Triyono, \& Amanda Wahid, D. (2021). Law Enforcement of Land Transfer from Agricultural Land to Housing in Indonesia. E3S Web of Conferences, 232, 1-19. https://doi.org/10.1051/e3sconf/202123204008 